\title{
Health Care Reform's Unfinished Work - Remaining Barriers to Coverage and Access
}

\section{Citation}

Sommers, Benjamin D. 2015. “Health Care Reform's Unfinished Work - Remaining Barriers to Coverage and Access.” N Engl J Med (October 28): 151029063058001. doi:10.1056/ nejmp1509462.

\section{Published Version}

doi:10.1056/NEJMp1509462

\section{Permanent link}

http://nrs.harvard.edu/urn-3:HUL.InstRepos:23508738

\section{Terms of Use}

This article was downloaded from Harvard University's DASH repository, and is made available under the terms and conditions applicable to Other Posted Material, as set forth at http:// nrs.harvard.edu/urn-3:HUL.InstRepos:dash.current.terms-of-use\#LAA

\section{Share Your Story}

The Harvard community has made this article openly available.

Please share how this access benefits you. Submit a story.

\section{Accessibility}



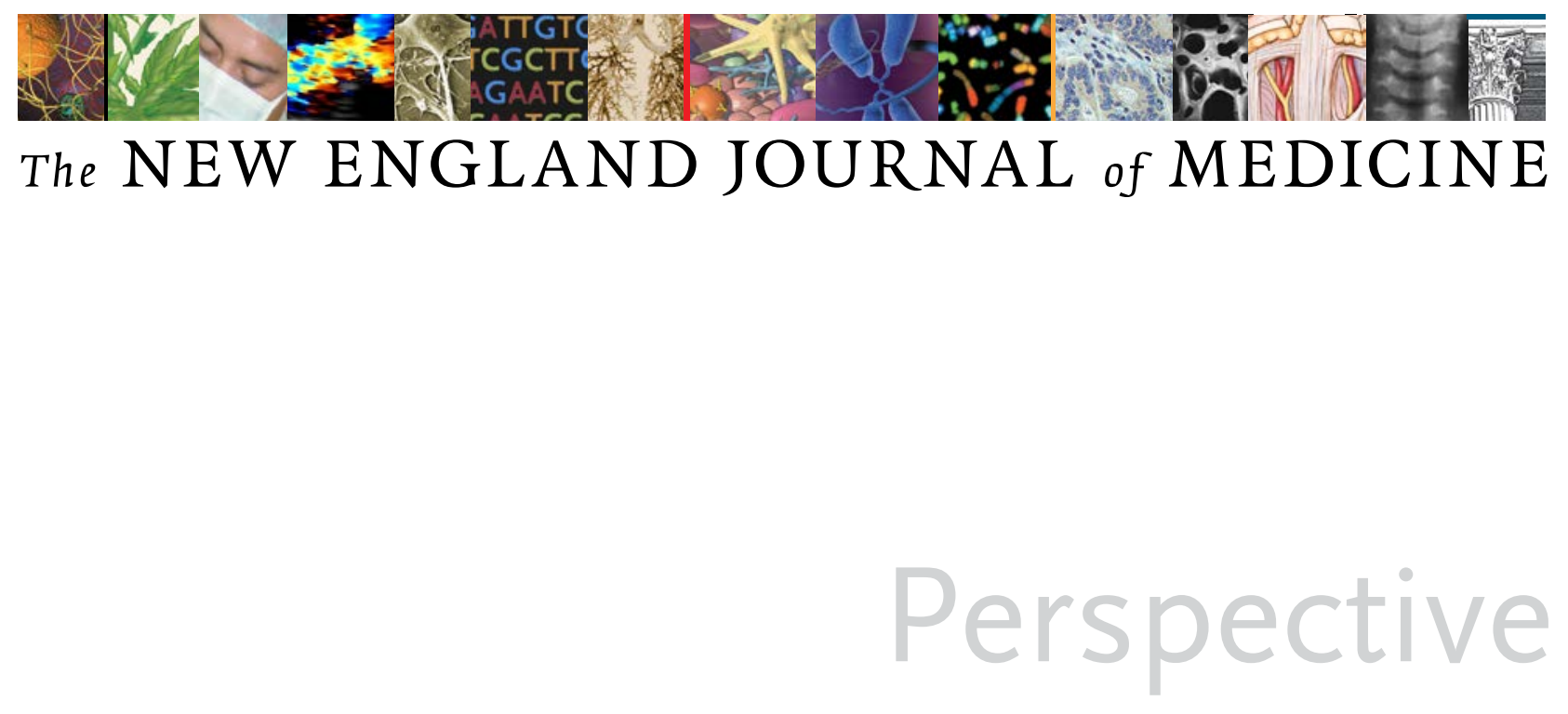

\section{Health Care Reform's Unfinished Work - Remaining Barriers to Coverage and Access}

Benjamin D. Sommers, M.D., Ph.D.

The Affordable Care Act (ACA) has passed its fifth
birthday and completed two enrollment periods for coverage in the state-based insurance exchanges and Medicaid. The U.S. uninsured rate is lower than

ever, and coverage gains appear to be improving access to primary care and medications, affordability of care, and self-reported health. ${ }^{1}$ But challenges for health care reform persist: millions of Americans are still uninsured, and even for those with coverage, substantial barriers remain to obtaining affordable, high-quality care.

More than 30 million U.S. children and adults still lack insurance (see pie chart). Who are they, and what policy options exist for covering them?

One group is low-income adults in the 20 states that haven't expanded Medicaid under the ACA. The law envisioned a seamless set of insurance options: Medicaid for people with incomes below 138\% of the poverty level and tax credits for those with incomes between 138 and $400 \%$ of the poverty level to subsidize premiums for insurance purchased through state-based exchanges. But 3 million to 4 million uninsured adults in states that haven't expanded Medicaid are caught in the "Medicaid gap": their incomes exceed their states' Medicaid eligibility criteria but are too low to qualify them for exchange subsidies. Several Republican-led states are still seeking compromises to expand Medicaid, and the Obama administration can continue to facilitate Medicaid expansion in conservative states by supporting flexibil- ity for alternative approaches. As a stopgap, Congress could extend insurance tax credits to persons living below the poverty level who are not Medicaid-eligible, though they might find even heavily subsidized premiums unaffordable.

Approximately two thirds of remaining uninsured people are eligible for coverage but haven't signed up, or did so but then dropped out. Most of them have incomes below $400 \%$ of the poverty level and qualify for subsidized insurance. ${ }^{2}$ So why are millions still uninsured?

Many Americans remain unaware of the ACA's coverage options. ${ }^{3}$ Ongoing media and community-based outreach particularly to adults with low incomes, minimal health care experience, or cultural or language barriers - is needed. Navigators and other trained workers can help people apply, ${ }^{3}$ select the most 


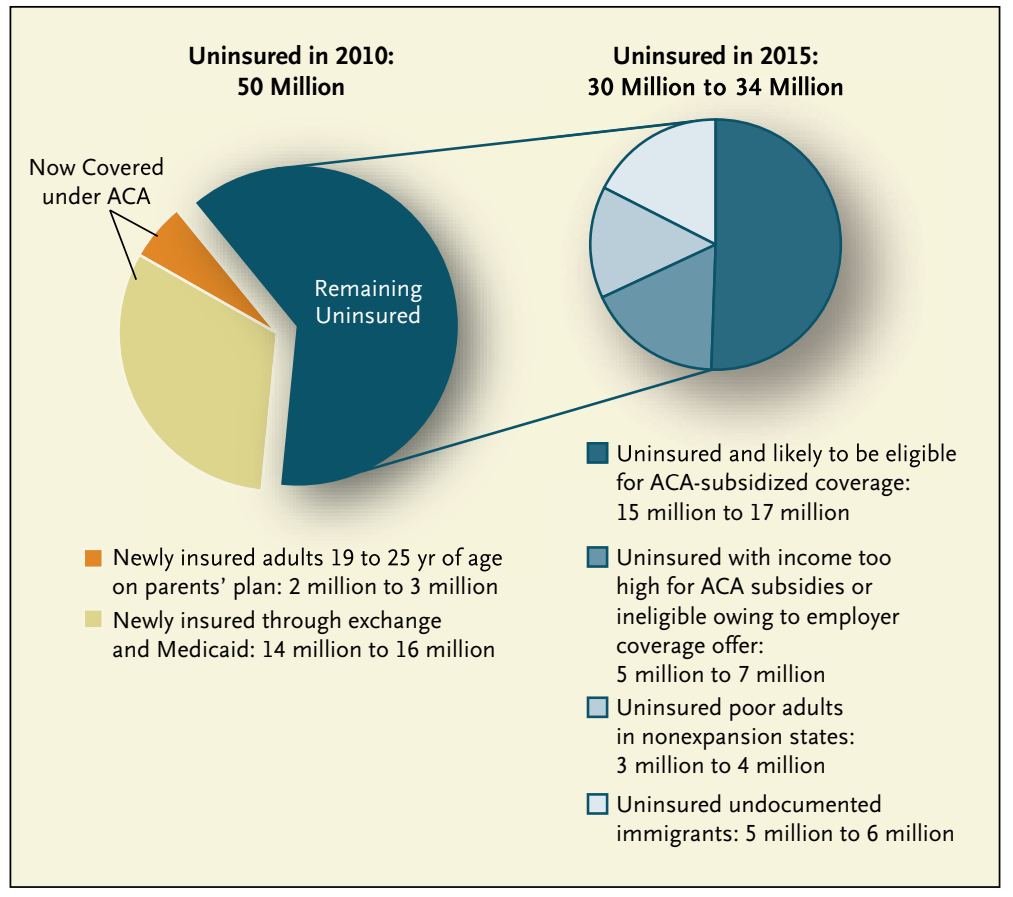

Changes in the Composition of the Uninsured Population between 2010 and 2015. Estimates adapted from the 2010 Current Population Survey, Sommers et al., ${ }^{1}$ Garfield et al., ${ }^{2}$ the Office of the Assistant Secretary for Planning and Evaluation, and the Kaiser Family Foundation.

appropriate coverage, and maneuver through coverage changes over time. However, some states, driven largely by political opposition to the law, have enacted regulations to reduce the availability of application assistance, doing their uninsured populations a major disservice.

For many Americans who know about the ACA's options but choose not to enroll, cost is the most significant barrier. In particular, some people with higher incomes qualify for little or no premium subsidy for exchange coverage. Facing a penalty that remains substantially lower than a year's worth of premiums, some have decided against purchasing coverage. Policy options here include increasing subsidies for higherincome families and strengthening the mandate that individuals obtain insurance - though the former would be quite costly and the latter would further antagonize most opponents of the mandate. Another alternative is replacing the mandate with incentives similar to those in Medicare Parts B and D: higher premiums for each month that a person chooses not to obtain coverage. ${ }^{4}$ But it's unclear how easy it would be to implement such a policy for people younger than 65 who regularly cycle in and out of coverage, unlike the Medicare population. More broadly, efforts to control health care costs and thus premium growth will help determine whether coverage rates continue to climb.

Finally, about 20 to $25 \%$ of the remaining uninsured population consists of undocumented immigrants, who are excluded from the ACA's coverage expansion. Although some states are considering options for providing insurance to this population using state funds, a national solution will probably remain elusive absent comprehensive immigration reform.

Meanwhile, even for people who gained insurance under the ACA and the tens of millions who already had coverage, substantial barriers to timely access to affordable medical care remain. Two features of exchange-based coverage - high cost sharing and narrow provider networks can limit access and are increasingly common in employer-sponsored plans as well. The average deductible in 2015 was just under $\$ 3,000$ for silver-level exchange plans and \$5,200 for bronze-level plans. Deductibles can reduce costs by discouraging the use of low-value care, but they may also drive patients to skimp on necessary care. Insurance designs could instead reduce financial barriers for high-value care while maintaining cost sharing for remaining services. The ACA takes a step in this direction by requiring evidence-based preventive services to be covered without cost sharing, but sensible plan design would similarly encourage ongoing management for chronic conditions such as diabetes, heart disease, and hypertension, without patients first having to exhaust several thousand dollars in out-of-pocket spending.

Narrow networks are another area that demand nuanced policy. This phenomenon, too, derives from competition among plans to keep premiums down. Though patients generally dislike restrictions on where they can obtain care, narrow networks could conceivably reduce spending without harming quality. 
This approach can be taken too far, however, and reports that some plans are entirely excluding certain specialties from their networks indicate that greater oversight is needed. ${ }^{5}$ Similar concerns exist in Medicaid, in which the costs of higher provider reimbursements must be weighed against enhanced access for beneficiaries.

These considerations notwithstanding, the ACA is succeeding in expanding coverage and access, with promising indications for population health. ${ }^{1}$ But challenges remain; the fundamental political question is how - and whether - they'll be addressed. Though some members of both political parties favor replacing the ACA entirely, that seems unlikely to happen. Liberals who believe a single-payer system is the easiest method of eliminating cracks in our patchwork coverage approach must face the political realities that derailed a single-payer effort in liberal Vermont and have made it so challenging to implement even a centrist national health care reform law. Many conservatives still advocate "repeal and replace," but the almost-certain backlash against taking coverage away from more than 15 million Americans makes it hard to imagine this rhetoric becoming reality, even if Republicans control Congress and the White House after 2016.

What's likely, then, is health care reform version 1.1, rather than version 2.0. We'll probably see substantial debate over refining the $\mathrm{ACA}^{4}$ rather than replacing it, much as occurred after the enactment of Medicaid and Medicare in 1965. Perspectives on how to do so will vary; some policymakers will argue that the law isn't generous enough, while others will insist that it's already too costly and intrusive. Ultimately, there are likely to be only incremental changes - which will be warranted, since there's still much to be done to improve coverage and access to care for all Americans.

Disclosure forms provided by the author are available with the full text of this article at NEJM.org.

From the Department of Health Policy and Management, Harvard T.H. Chan School of Public Health, Boston.

This article was published on October 28, 2015, at NEJM.org.

1. Sommers BD, Gunja MZ, Finegold K, Musco T. Changes in self-reported insurance coverage, access to care, and health under the Affordable Care Act. JAMA 2015;314:36674.

2. Garfield R, Damico A, Cox C, Claxton G, Levitt L. New estimates of eligibility for ACA coverage among the uninsured. Washington, DC: Kaiser Family Foundation, 2015.

3. Sommers BD, Maylone B, Nguyen $\mathrm{KH}$, Blendon RJ, Epstein AM. The impact of state policies on ACA applications and enrollment among low-income adults in Arkansas, Kentucky, and Texas. Health Aff (Millwood) 2015;34:1010-8.

4. Wilensky GR. Improving and refining the Affordable Care Act. JAMA 2015;314:339-40. 5. Dorner SC, Jacobs DB, Sommers BD. Adequacy of outpatient specialty care access in marketplace plans under the Affordable Care Act. JAMA 2015;314:1749-50.

DOI: 10.1056/NEJMp1509462

Copyright (๑) 2015 Massachusetts Medical Society. 